\title{
THE EFFECT OF FINANCIAL LEVERAGE ON FIRM VALUE AND MARKET RISK \\ (Research on Consumer Goods Industries Listed In Indonesian Stock Exchange In The Year of 2010-2012)
}

\author{
${ }^{1)}$ Erindah Dimisyqiyani, ${ }^{2)}$ Suhadak, ${ }^{3)}$ Kertahadi \\ ${ }^{123)}$ Fakultas Ilmu Administrasi Universitas Brawijaya \\ ${ }^{1)}$ Email: erindah.dimisyqiyani@gmail.com
}

\begin{abstract}
ABSTRAK
Penelitian ini menguji pengaruh leverage keuangan terhadap nilai perusahaan dan risiko pasar, tempat penelitian di industri barang konsumsi yang terdaftar di Bursa Efek Indonesia pada tahun 2010-2012. peneliti menggunakan analisis jalur. Data dikumpulkan dari 13 perusahaan dengan laporan tahunan. Penelitian ini menunjukkan bahwa variabel Gelar Financial Leverage (DFL) memiliki efek positif yang signifikan pada variabel Earning Per Share (EPS). Variabel Gelar Financial Leverage (DFL) memiliki pengaruh yang signifikan positif terhadap variabel Return On Equity (ROE). Variabel Debt Ratio (DR) memiliki negatif dan efek non-signifikan pada variabel Earning Per Share (EPS). Variabel Debt Ratio (DR) memiliki negatif dan efek non-signifikan terhadap variabel Return On Equity (ROE). Variabel Gelar Financial Leverage (DFL) memiliki pengaruh yang signifikan positif terhadap variabel risiko pasar ( $\beta$ ). Variabel Debt Ratio (DR) memiliki pengaruh yang signifikan positif terhadap variabel risiko pasar $(\beta)$. Variabel risiko pasar $(\beta)$ memiliki pengaruh yang signifikan positif terhadap variabel Earning Per Share (EPS). Variabel risiko pasar $(\beta)$ memiliki pengaruh yang signifikan positif terhadap variabel Return On Equity (ROE).
\end{abstract}

\section{Kata kunci: Financial Leverage, Nilai Perusahaan, Risiko Pasar}

\begin{abstract}
This study examines the effect of financial leverage on firm value and market risk, the place of research in consumer goods industries listed in Indonesian stock exchange in the year of 2010-2012. The researcher uses path analysis. Data were collected from 13 companies by annual report. The research suggests that the variable of Degree of Financial Leverage (DFL) has a positive significant effect on the variable of Earning Per Share (EPS). The variable of Degree of Financial Leverage (DFL) has a positive significant effect on the variable of Return On Equity (ROE). The variable of Debt Ratio (DR) has a negative and a non-significant effect on the variable of Earning Per Share (EPS). The variable of Debt Ratio (DR) has a negative and a non-significant effect on the variable of Return On Equity (ROE). The variable of Degree of Financial Leverage (DFL) has a positive significant effect on the variable of market risk $(\beta)$. The variable of Debt Ratio (DR) has a positive significant effect on the variable of market risk ( $\beta)$. The variable of market risk ( $\beta$ ) has a positive significant effect on the variable of Earning Per Share (EPS). The variable of market risk $(\beta)$ has a positive significant effect on the variable of Return On Equity (ROE).
\end{abstract}

Keywords: Financial Leverage, Firm Value, Market Risk 


\section{INTRODUCTION}

A company produces goods for obtaining a target of profit. Profit is obtained by a company from the total revenue minus production costs incurred by a company. While a company tries to get a maximum profit, the company should keep producing with a minimum cost. If a company wants to produce goods, the company must have a sufficient fund to operate smoothly. One of the sources of the fund commonly used by a company comes from the external sources of funding. It means that the fund is not available from the operation of the company. It derives from other parties outside the company.

The operation of a company does not always run smoothly. If the company is experiencing constraints in operation and requires more funding, it must cover the required costs. If the fund needed is internally insufficient, then the fund is covered by leverage. When the company gets loan with fixed charges from the outside of the company, it will arise debt as a consequence of the loan. This suggests that the company has financial leverage.

Financial leverage can say that a firm with debt on its balance sheet is a levered firm, and a firm that finances its operations entirely with equity is an unlevered firm. That effect can be either positive or negative, depending on the returns a firm earns on the money it borrows (Megginson, et al, 2007). A manager has to know the 
condition of a company before using the financial leverage. A Leverage is obtained not only on the fund for production but it is also taken to increase the profits for shareholders. A manager has to figure out the firm value, which can be determined by measuring its EPS and ROE. The most common measurements of the company performance are earnings per share (EPS) and the result of return on equity (ROE) (Weston and Copeland, 2010 p. 195).

An analyst of PT Batavia Prosperindo Securities Julio Parningotan (2012) in Azhar (2012), suggested investors to avoid the shares of Bakrie group for a while, following the falling stock of Bakrie Group last few days. He recommended that the investors turn to investing stocks of the consumer and the infrastructure sector, which were tended rising lately. Unlike

BUMI which is affected by international commodity, consumer and infrastructure

sectors tend to be defensive on the global economy (http://www.tempo.com).

Based on the previous analysis, the researcher wants to know the effect of financial leverage variables on firm value and market risk. Financial leverage variables in this study consisted of DR and DFL. Variables of firm value in this research consisted of EPS and ROE. Intervening variable in this research is

market risk.

The researcher took the object of

research in the consumer goods industries companies on the Indonesian Stock Exchange. The researcher choose the consumer goods industries because the companies produces products that are often consumed by consumers. This causes the market share of product of consumer goods industries not only to a specific community like other industrial products, but also to the middle-market segment up or down the

middle. So, the industries have good prospect and can maintain the firm's value in order stay well. Consumer goods

industries have a strong sector for consumer products primarily needed of people. The level of demand is quite stable against a wide range of consumer products with global situation showing defensive nature of the consumer's sector, especially for consumer goods in the territory of Indonesia where the target market of consumer goods is human.

\section{THEORETICAL BACKGROUND AND HYPOTESIS}

\section{A. Leverage}

According Anderson (1987, p. 38) Leverage: the use of fixed charge obligations with the intent of magnifying the potential return to the firm. Financial leverage: a measure of the amount of debt used in the capital structure of the firm. Financial leverage is beneficial only if the firm can employ the borrowed funds to ear a higher rate of return than the interest rate on the borrowed amount. Leverage ratio can be calculated by using the formula:

$$
\begin{aligned}
& \text { Total Debt } \\
& \text { Ratio }
\end{aligned}=\frac{\text { Total Liabilities }}{\text { Total Assets }}
$$

(Brealey, et al, 2001, p. 138)

Financial leverage defines that a firm with debt on its balance sheet is a levered firm. Debt effect can be either positive or negative, depending on the returns a firm earns on the money it borrows (Megginson, et al, 2007, p. 451). The degree of financial leverage (DFL) can be computed more easily as follows:

\section{Earnings Before Interest and}

$$
\mathrm{DFL}=\frac{\text { Tax }}{\text { Earning Before Tax }}
$$

(Gibson, 2009, p. 336)

\section{B. Return On Equity (ROE)}

Return On Equity (ROE) is a measure of how the stockholders fared during the year. Because benefiting shareholders is our goal, ROE is, in an accounting sense, the true bottomline measure of performance. ROE is usually measured as:

$\begin{aligned} & \text { Return } \\ & \text { On } \\ & \text { Equity }\end{aligned} \quad=\frac{\text { Net Income }}{\text { Total Equity }}$

(Ross, et al, 2008, p. 53) 


\section{Earning Per Share (EPS)}

Computing earnings per share initially involves net income, preferred stock dividend declared and accumulated, and the weighted average number of shares outstanding, as follows:

\begin{tabular}{|c|c|c|}
\hline & & $\begin{array}{l}\text { Net Income - Preferred } \\
\text { Dividends }\end{array}$ \\
\hline EPS & $=$ & $\begin{array}{l}\text { Weighted Average Number of } \\
\text { Common Shares Outstanding }\end{array}$ \\
\hline
\end{tabular}

(Gibson, 2009, p. 338)

\section{Market Risk}

We know the performance of the market reflects only macro events, because firm-specific events-that is, unique risks- average out when we look at the combined performance of thousands of companies and securities. In principle the market portfolio should contain all assets in the world economy-not just stocks, but bonds, foreign securities, real estate, and so on. In practice, however financial analysts make do with indexes of the stock market, usually the Standard and Poor's Composite Index (the S\&P 500). Our task here is to define and measure the risk of individual common stocks. You can probably see where we are headed. Risk depends on exposure to macroeconomic events and can be measured as the sensitivity of a stock's returns to fluctuations in returns on the market portfolio. This sensitivity is called the stock's beta. Beta is often written as the Greek letter $\beta$ (Brealey et al, 2001, p. 408).

The contribution of a stock to the risk of a well-diversified portfolio, we should not look at risk if the shares are owned separately, but we have to measure the market risk and bring us to measure sensitivity to change market. Profit rate sensitivity to changes of market is called beta investment (Husnan, 1990). Beta is usually measured as:

$$
\beta=\frac{\operatorname{Cov}(\mathrm{Ri}-\mathrm{RM})}{\sigma^{2}(\mathrm{RM})}
$$

(Husnan, 1990 p. 139-140)

\section{RESEARCH METHOD}

The researcher uses explanatory research with quantitative approach for researching type. Quantitative approach- post positivist worldview, experimental strategy of inquiry, and pre- and post-test measures of attitudes. In this scenario, the researcher tests a theory by specifying

narrow hypotheses and the collection of data to support or refute the hypotheses. An experimental design is used in which attitudes are assessed both before and after an experimental treatment. The data are collected on an instrument that measures attitudes, and the information is analyzed using statistical procedures and hypothesis testing (Creswell, 2009:16). Explanatory research is a research that aims to test a theory or hypothesis to strengthen or even reject the theory or hypothesis of existing research results.

The independent variable consists of Degree of Financial Leverage (DFL) (X1) and Debt to Total Assets (DR) (X2) on firm's value with the dependent variables consist of Earnings Per Share (EPS) (Y1) and Return On Equity (ROE) (Y2) and the intervening variable is market risk $(\mathrm{Z})$ on the consumer goods industries listed in Indonesian Stock Exchange in the year of 2010-2012. The research was conducted in Indonesian Stock Exchange in University of Brawijaya. The researcher chooses this location because the companies, whose financial statements have been audited by a public accountant and published is incorporated in the IDX that have gone public.

The purpose of sampling in this research was to determine the financial statements of the companies on the consumer goods industries listed in Indonesian Stock Exchange in the year of

2010-2012.

Below are the companies that used in the sample:

1. PT Indofood Sukses Makmur Tbk

2. PT Mayora Indah Tbk

3. PT Gudang Garam Tbk

4. PT Hanjaya Mandala Sampoerna Tbk

5. PT Kalbe Farma Tbk 
6. PT Tempo Scan Pacific Tbk

7. PT Unilever Indonesia Tbk

8. PT Akasha Wira International Tbk

9. PT Ultajaya Milk Industry and Trading Company Tbk

10. PT Kimia Farma (Persero) Tbk

11. PT Darya Varia Laboratoria Tbk

12. PT Indofarma ( Persero ) Tbk

13. PT Taisho Pharmaceutical Indonesia Tbk

\section{Hypotheses Testing and Discussion}

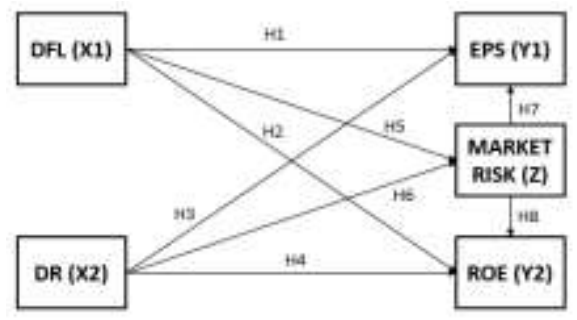

Figure 1 shows conceptual model of this research. There are 8 hypotheses:

H1 : The Degree of Financial leverage (DFL) affects Earning Per Share (EPS)

H2 : The Degree of Financial leverage (DFL) affects Return On Equity (ROE)

H3 : The Debt Ratio (DR) affects Earning Per Share (EPS)

H4 : The Debt Ratio (DR) affects Return On Equity (ROE)

H5 : The Degree of Financial Leverage (DFL) affects market risk

H6 : The Debt Ratio (DR) affects market risk

H7 : The Market risk affects Earning Per Share (EPS)

H8 : The Market risk affects Return On Equity (ROE)

\section{Conclusion of This Research}

Table 1 . Concept and Indicator

\begin{tabular}{|c|c|c|}
\hline Concept & Variable & Indicator \\
\hline \multirow[b]{2}{*}{$\begin{array}{l}\text { Financial } \\
\text { Leverage }\end{array}$} & $\begin{array}{c}\text { Degree of } \\
\text { Financial } \\
\text { Leverage } \\
\text { (DFL) } \\
\text { (X1) }\end{array}$ & $\begin{array}{c}\text { Earnings Before } \\
\frac{\text { Interest and Tax }}{\text { Earning Before }} \\
\text { Tax }\end{array}$ \\
\hline & $\begin{array}{l}\text { Debt to } \\
\text { Total } \\
\text { Assets } \\
\text { (DR) (X2) }\end{array}$ & $\begin{array}{c}\frac{\text { Total }}{\text { Liabilities }} \\
\text { Total } \\
\text { Assets }\end{array}$ \\
\hline
\end{tabular}

\begin{tabular}{|c|c|c|}
\hline Concept & Variable & Indicator \\
\hline \multirow{7}{*}{$\begin{array}{c}\text { Firm } \\
\text { Value }\end{array}$} & $\begin{array}{c}\text { Earning } \\
\text { Per Share } \\
\text { (EPS) (Y1) }\end{array}$ & $\begin{array}{c}\text { Net Income - Preferred } \\
\text { Dividends Weighted } \\
\text { Average Number of } \\
\text { Common Shares } \\
\text { Outstanding }\end{array}$ \\
\cline { 2 - 3 } & $\begin{array}{c}\text { Return On } \\
\text { Equity } \\
\text { (ROE) } \\
\text { (Y2) }\end{array}$ & $\begin{array}{c}\text { Net Income } \\
\text { Total Equity }\end{array}$ \\
\hline Risk & $\begin{array}{c}\text { Market } \\
\text { Risk (Z) }\end{array}$ & $\beta=\frac{\operatorname{Cov}\left(\mathrm{R}_{\mathrm{i}}-\mathrm{RM}_{\mathrm{M}}\right)}{\sigma^{2}\left(\mathrm{R}_{\mathrm{M}}\right)}$ \\
\hline
\end{tabular}

Source: Processed Data (2014)

Based on the hypothesis that has been formulated, the analysis of the data used in this study is the Path Analysis. According Ghozali (2012:249) Path analysis is an extension of the multiple linear regression analysis or the use of regression analysis to estimate the causal relationship among variables (casual model) predetermined by the theory. Path analysis cannot determine causality and cannot be used as a substitute by the researchers to see the causal relationship among variables. Causality among variables has been established with a model based on a theoretical foundation. Path analysis is used to determine the relationship among three or more variables and cannot be used to confirm or reject the hypothesis of causality imaginary.

\section{RESULT AND DISCUSSION}

\section{A. Path Statistical Analysis}

Table 2. The result of testing DFL (X1) and

DR (X2) on $\beta$ (Z) (Variable X1, X2

On The Variable $Z$ )

\begin{tabular}{|c|c|c|c|c|}
\hline $\begin{array}{l}\text { Independent } \\
\text { Variable }\end{array}$ & $\begin{array}{c}\text { Standardized } \\
\begin{array}{c}\text { Coefficients } \\
\text { beta }\end{array} \\
\end{array}$ & $t_{\text {count }}$ & Probability & Information \\
\hline X1 (DFL) & 0.398 & 3.362 & 0.002 & Significant \\
\hline X2 (DR) & 0.518 & 4.375 & 0.000 & Significant \\
\hline $\begin{array}{l}\text { Dependent } \\
\text { Variable }\end{array}$ & \multicolumn{4}{|c|}{ : Z (Market Risk ( $(\beta))$} \\
\hline $\mathbf{R}$ & $: 0.722$ & & & \\
\hline$R$ square $\left(\mathbf{R}_{2}\right)$ & $: 0.522$ & & & \\
\hline Adjusted $R$ square & $: 0.495$ & & & \\
\hline $\begin{array}{l}\mathbf{F}_{\text {count }} \\
\text { Probability } \mathbf{F}_{\text {count }}\end{array}$ & $\begin{array}{l}: 19.623 \\
: 0.000\end{array}$ & & & \\
\hline
\end{tabular}

Source: Processed Data from IDX (2014) 


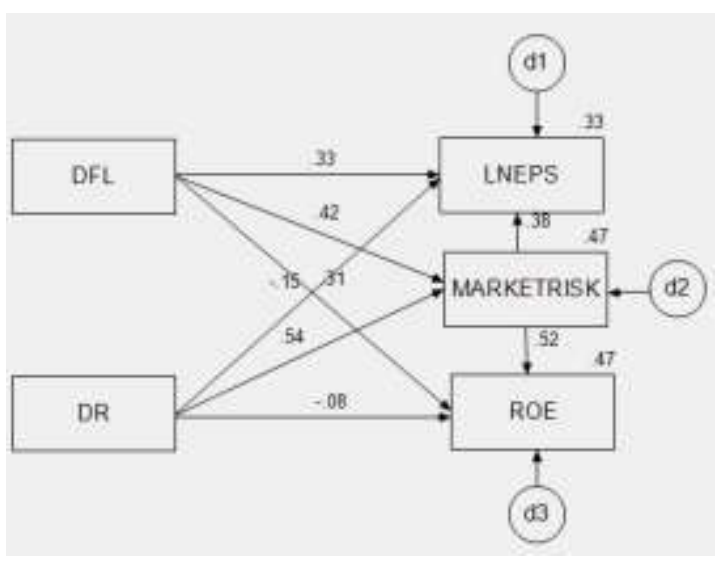

Figure 2. The Result Of Path Coefficient

Table 3. Path Coefficient value

\begin{tabular}{|c|c|c|c|}
\hline \multicolumn{3}{|c|}{ variable } & Estimate \\
\hline $\begin{array}{l}\text { MARKET } \\
\text { RISK }\end{array}$ & $<---$ & DFL & 0.418 \\
\hline $\begin{array}{l}\text { MARKET } \\
\text { RISK }\end{array}$ & $<--$ & DR & 0.545 \\
\hline LNEPS & $<--$ & DFL & 0.334 \\
\hline ROE & $<--$ & DFL & 0.310 \\
\hline LNEPS & $<---$ & DR & -0.146 \\
\hline ROE & $<---$ & DR & -0.076 \\
\hline ROE & $<---$ & $\begin{array}{l}\text { MARKET } \\
\text { RISK }\end{array}$ & 0.523 \\
\hline LNEPS & $<---$ & $\begin{array}{l}\text { MARKET } \\
\text { DICV }\end{array}$ & 0.383 \\
\hline
\end{tabular}

Source: Processed Data from IDX (2014)

The coefficient of determination is a coefficient that shows the influence or contribution of endogenous and exogenous variables on variables of one endogenous to other endogenous variables. Here are the test results that demonstrate the value of the coefficient of determination:

Table 4. Coefficient value of determination

\begin{tabular}{|c|c|}
\hline Variable & $\mathbf{R}^{\mathbf{2}}$ \\
\hline $\begin{array}{c}\text { Degree of Financial Leverage } \\
\text { (DFL), Total Debt Ratio } \\
\text { (DR) and Market Risk }(\beta) \Rightarrow \\
\text { Return On Equity (ROE) }\end{array}$ & 0.494 \\
\hline $\begin{array}{c}\text { Degree of Financial Leverage } \\
\text { (DFL), Total Debt Ratio (DR) } \\
\text { and Market Risk ( } \beta \text { ) } \Rightarrow\end{array}$ & 0.334 \\
Earning Per Share (EPS) & \\
\hline $\begin{array}{c}\text { Degree of Financial Leverage } \\
\text { (DFL) and Total Debt Ratio } \\
(\mathrm{DR}) \Rightarrow \text { Market Risk ( } \beta \text { ) }\end{array}$ & 0.522 \\
\hline \multicolumn{2}{|c|}{ Source Processed Data from IDX $(2014)$} \\
\hline
\end{tabular}

Source: Processed Data from IDX (2014)

\section{B. Direct Effect, Indirect Effect And Total Effect}

Table 5. Direct Effect

\begin{tabular}{|l|rrr|}
\hline & DR & DFL & $\begin{array}{c}\text { MARKET } \\
\text { RISK }\end{array}$ \\
\hline MARKET & 0.545 & 0.418 & 0.000 \\
RISK & -0.076 & 0.310 & 0.523 \\
ROE & -0.146 & 0.334 & 0.383
\end{tabular}

Source: Processed Data from IDX (2014)

Table 6. Indirect Effect

\begin{tabular}{|l|rrr|}
\hline & DR & DFL & $\begin{array}{c}\text { MARKET } \\
\text { RISK }\end{array}$ \\
\hline MARKET & 0.000 & 0.000 & 0.000 \\
RISK & 0.285 & 0.219 & 0.000 \\
ROE & 0.208 & 0.160 & 0.000 \\
LNEPS
\end{tabular}

Source: Processed Data from IDX (2014)

Table 7. Total Effect

\begin{tabular}{|l|rrr|}
\hline & DR & DFL & $\begin{array}{c}\text { MARKET } \\
\text { RISK }\end{array}$ \\
\hline MARKET & 0.545 & 0.418 & 0.000 \\
RISK & 0.209 & 0.529 & 0.523 \\
ROE & 0.062 & 0.494 & 0.383 \\
LNEPS
\end{tabular}

Source: Processed Data from IDX (2014)

\section{The Result of Hypothesis Testing}

Table 8. The Hypothesis Result Testing Of Direct Effect

\begin{tabular}{|l|l|l|r|r|r|c|}
\hline \multicolumn{3}{|c|}{ Variable } & $\begin{array}{r}\text { Estim } \\
\text { ate }\end{array}$ & S.E. & C.R. & P \\
\hline $\begin{array}{l}\text { MARKET } \\
\text { RISK }\end{array}$ & $<-$ & DFL & .036 & .010 & 3.454 & .000 \\
\hline $\begin{array}{l}\text { MARKET } \\
\text { RISK }\end{array}$ & $<-$ & DR & .965 & .215 & 4.495 & .000 \\
\hline LNEPS & $<-$ & DFL & .196 & .092 & 2.126 & .033 \\
\hline ROE & $<-$ & DFL & .028 & .012 & 2.224 & .026 \\
\hline LNEPS & $<-$ & DR & -1.794 & 2.078 & -.863 & .388 \\
\hline ROE & $<-$ & DR & -.141 & .280 & -.503 & .615 \\
\hline ROE & $<-$ & $\begin{array}{l}\text { MARKET } \\
\text { RISK }\end{array}$ & .549 & .171 & 3.216 & .001 \\
\hline LNEPS & $<-$ & $\begin{array}{l}\text { MARKET } \\
\text { RISK }\end{array}$ & 2.646 & 1.268 & 2.086 & .037 \\
\hline SOUIC & PIOCE & & & \\
\hline
\end{tabular}

Source: Processed Data from IDX (2014)

Based on the table 8, the result of hypothesis testing in this research are as follows:

H1 : Hypothesis 1 shows that there is significant effect from the variable of Degree of Financial Leverage (X1) on variable of Earning Per Share (EPS) (Y1). The result of the calculation from the variable of Degree of Financial Leverage (XI) effect on the variable of Earning Per Share (EPS) (YI) 
that there is a significant result (with a probability value of $0.033<0.05$ ) and critical ratio is equal to $2.126>1.96$. It can be concluded that the research results support the hypothesis 1 . The Degree of Financial Leverage variable (X1) has positive influence on Earning Per Share (EPS) (Y1) with coefficient of Degree of Financial Leverage (DFL) which affects the Earning Per Share (EPS) as much as 0.196. In other words if $D F L$ increases 1 unit, then the Earning Per Share (EPS) will also increase to 0.196. If $D F L$ decreases 1 unit, then the Earning Per Share (EPS) will also decrease to 0.196 .

H2 : Hypothesis 2 shows that there is significant effect from the variable of Degree of Financial Leverage (X1) on variable of Return On Equity (Y2). The result of the calculation from the variable of Degree of Financial Leverage variable (XI) effect on the variable of Return On Equity (Y2) shows that there is a significant result (with a probability value of $0.026<$

0.05 ) and critical ratio is equal to $2.224>1.96$. It can be concluded that the research results support the hypothesis 2 . The Degree of Financial Leverage variable (XI) has a significant effect and positive influence on Return On Equity (Y2) with coefficient of Degree of Financial Leverage (DFL) which affects the Return On Equity $(Y 2)$ as much as 0.028 . In other words, if DFL increases 1 unit, then the Return On Equity (Y2) will also increase to 0.028. If $D F L$ decreases 1 unit, then the Return On Equity (Y2) will also decrease to 0.028 .

H3 : Null hypothesis 3 shows that there is no significant effect from the variable of Debt to Total Assets (DR) (X2) on variable of Earnings Per Share (EPS) (Y1). The result of the calculation from the variable of Debt to Total Assets (DR) (X2) effect on the variable of Earnings Per Share (EPS) (Y1) shows that there is no significant result (with a probability value of $0.388>0.05$ ) and critical ratio is equal to $-.863<1.96$. This result suggests that the researcher has to receive $\mathrm{H} 0$ or null hypothesis that there is no effect from Debt to Total Assets (DR) (X2) on Earnings Per Share (EPS) (Y1) and the researcher has to reject alternative hypothesis or $\mathrm{H} 3$ suggests that there is effect of Debt to Total Assets (DR) (X2) on Earnings Per Share (EPS) (Y1). It can be concluded that the research results does not support the hypothesis 3 . Because, in the year of research, the value of Earnings Per Share (EPS) greater than Debt to Total Assets (DR). According to Brealey, et al (2001, p. 98-99) " A firm can achieve a higher growth rate without raising external capital if (1) it plows back a high proportion of its earnings, (2) it has a high return on equity (ROE), and (3) it has a low debt- toasset ratio. The firm issues only enough debt to keep its debt-equity ratio constant. The sustainable growth rate is the highest growth rate the firm can maintain without increasing its financial leverage." The Debt to Total Assets (DR) has no significant effect and shows a negative influence on the variable of Earnings Per Share (EPS) with coefficient of Debt to Total Assets (DR) which affects the Earning Per Share (EPS) as much as -1.794 . In other words if Debt to Total Assets (DR) increases 1 unit, then the Earnings Per Share (EPS) will be decreased is equal to -1.794. If Debt to Total Assets (DR) decreases 1 unit, then the Earnings Per Share (EPS) will increase to -1.794.

H4 : Null hypothesis 4 shows that there is no significant effect from the variable of Debt to Total Assets (DR) (X2) on variable of Return On Equity (Y2). The result of the calculation from the variable of Debt to Total Assets (DR) (X2) effect on the variable of Return On Equity (Y2) shows that there is significant result (with a probability value of $0.615>0.05$ ) and critical ratio 
is no equal to $-0.503<1.96$. This result suggests that the researcher has to receive $\mathrm{HO}$ or null hypothesis that there is no effect from Debt to Total Assets (DR) (X2) on Return On Equity (ROE) (Y2) and the researcher has to reject alternative hypothesis or $\mathrm{H} 4$ suggests that there is effect of Debt to Total Assets (DR) (X2) on Return On Equity (ROE) (Y2). It can be concluded that the research results does not support the hypothesis 4. Because, in the year of research, the value of Return On Equity (ROE) greater than Debt to Total Assets (DR). According to Brealey, et al (2001, p. 98-99) " A firm can achieve a higher growth rate without raising external capital if (1) it plows back a high proportion of its earnings, (2) it has a high return on equity (ROE), and (3) it has a low debt-toasset ratio. The firm issues only enough debt to keep its debt-equity ratio constant. The sustainable growth rate is the highest growth rate the firm can maintain without increasing its financial leverage." The Debt to Total Assets (DR) (X2) has no significant effect and negative influence on Return On Equity (Y2) with coefficient of Debt to Total Assets (DR) (X2) which affects the Return On Equity (Y2) as much as -

0.141. In other words if Debt to Total Assets (DR) increases 1 unit, then the Return On Equity (ROE) will decrease to 0.141. If Debt to Total Assets (DR) increases 1 unit, then the Return On Equity $(R O E)$ will decrease to -0.141 .

H5 : Hypothesis 5 shows that there is significant effect from the variable of Degree of Financial Leverage (X1) on variable of market risk $(\beta)(Z)$. The result of the calculation from the variable of

Degree of Financial Leverage (XI) effect on the variable of market risk $(\beta)(Z)$ shows that there is significant result (with a probability value of $0.000<0.05$ ) and critical ratio is equal of $3.454>1.96$. It can be concluded that the research result support the hypothesis 5. The Degree of Financial Leverage (XI) has significant effect and positive influence on market risk (B) (Z) with coefficient of Degree of Financial Leverage (XI) which affects the market risk $(\beta)(Z)$ as much as 0.036 . In other words if Degree of Financial Leverage (X1) increases 1 unit, then the market risk $(\beta)(Z)$ will also increase to 0.036 or 3.6 . If Degree of Financial Leverage $(X 1)$ decreases 1 unit, then the market risk $(\beta)(Z)$ will also decrease to 0.036 .

H6 : Hypothesis 6 shows that there is a significant effect from the variable of Debt to Total Assets (DR) (X2) on variable of market risk $(\beta)(Z)$. The result of the calculation from the variable of Debt to Total Assets (DR) (X2) effect on the variable of market risk ( $\beta)$ (Z) shows that there is significant result (with a probability value of $0.000<0.05$ ) and critical ratio is equal to $4.495>1.96$. It can be concluded that the research results support the hypothesis 6. The Debt to Total Assets (DR) (X2) has significant effect and positive influence on market risk $(\beta)(Z)$ with coefficient of Debt to Total Assets $(D R)$ (X2) which affects the market risk ( $\beta)$ $(Z)$ as much as 0.965 . In other words, if Debt to Total Assets (DR) (X2) increases 1 unit, then the market risk $(\beta)(Z)$ will also increase to

0.965. If Debt to Total Assets (DR) (X2) decreases 1 unit, then the market risk $(\beta)(Z)$ will also decrease to 0.965 .

H7 : Hypothesis 7 shows that there is a significant effect from the variable of market risk $(\beta)(Z)$ on variable of Earning Per Share (EPS) (Y1). The result of the calculation from the variable of market risk $(\beta)(Z)$ effect on the variable of Earning Per Share (EPS) (YI) shows that there is significant result (with a probability value of $0.037<0.05$ ) and critical ratio is equal of $2.086>1.96$. It can be concluded that the research results support the hypothesis 7 . The market 
risk ( $\beta)(Z)$ has significant effect and positive influence on Earning Per Share $(E P S)(Y 1)$ with coefficient of market risk $(\beta)(Z)$ which affects the Earning Per Share (EPS) (Y1) as much as 2.646. In other words if market risk $(\beta)(Z)$ increases 1 unit, then the Earning Per Share (EPS) (Y1) will also increase to 2.646. If market risk $(\beta)(Z)$ decreases 1 unit, then the Earnings Per Share (EPS) (Y1) will also decrease to 2.646.

H8 : Hypothesis 8 shows that there is a significant effect from the variable of market risk $(\beta)(Z)$ on variable of Return On Equity (Y2). The result of the calculation from the variable of market risk $(\beta)(Z)$ effect on the variable of Return On Equity (Y2) shows that there is significant result (with a probability value of $0.001<0.05$ ) and critical ratio is equal to $3.216>1.96$. It can be concluded that the research results support the hypothesis 8 . The market risk ( $\beta)(Z)$ has significant effect and positive influence on Return On Equity (Y2) with coefficient of market risk $(\beta)(Z)$ which affects the Return On Equity (Y2) as much as 0.549 . In other words if market risk $(\beta)$ $(Z)$ increases 1 unit, then the Return On Equity (Y2) will also increase to 0.549 or $54.9 \%$. If market risk $(\beta)(Z)$ decreases 1 unit, then the Return On Equity (Y2) will also decrease to 0.549 .

\section{CONCLUDING REMARK Concluding}

Based on the conducted calculation of

path analysis are:

1. The variable of Degree of Financial Leverage (DFL) (X1) has a positive significant effect on the variable of Earning Per Share (EPS) (Y1).

2. The variable of Degree of Financial Leverage (DFL) (X1) has a positive significant effect on the variable of Return On Equity (ROE) (Y2).

3. The variable of Debt Ratio (DR) (X2) has a negative and a non significant effect on the variable of Earning Per Share (EPS) (Y1).

4. The variable of Debt Ratio (DR) (X2) has a negative and a non significant effect on the variable of Return On Equity (ROE) (Y2).

5. The variable of Degree of Financial Leverage (DFL) (X1) has a positive significant effect on the variable of market risk $(\beta)(Z)$.

6. The variable of Debt Ratio (DR) (X2) has a positive significant effect on the variable of market risk $(\beta)(Z)$.

7. The variable of market risk $(\beta)(Z)$ has a positive significant effect on the variable of Earning Per Share (EPS) (Y1).

8. The variable of market risk $(\beta)(Z)$ has a positive significant effect on the variable of Return On Equity (ROE) (Y2).

\section{Remark}

1. For the management of the company, the results show that the DFL has a significant effect on EPS, ROE and market risk, DR has a significant effect on market risk, but there is no significant effect on $\mathrm{ROE}$ and EPS. The value of the highest critical ratio is the DR on the market risk which is 4.495. Then the company should be able to add value to the DR so that it will get the maximum benefit.

2. Increased DR will provide a positive contribution to Return on Equity and indirectly increases the Earning per Share, and increasing DR will increase market risk.

3. The result of this study can be used as a reference for other studies that uses the independent variables, namely DR and DFL, an intervening variable, namely market risk and the dependent variables, namely EPS and ROE. The amount of contribution variable of the Degree of Financial Leverage (DFL) (X1) and Debt to Total Assets (DR) (X2) on market risk ( $\beta$ ) (Z) which is 0.495 . This means that $49.5 \%$ variable market risk $(\beta)(\mathrm{Z})$ will be influenced by the independent variables. Then, a percentage of $50.5 \%$ 
is influenced by other variables that are not addressed in this research. To improve this condition, future studies should be able to make additions to the dependent variables, the intervening variables and the independent variables used.

\section{REFERENCES}

Brealey, Richard A; Myres, Stewart C; and Marcus, Alan J. 2001. Fundamentals of Corporate Finance: Third Edition. The McGraw-HillCompanies, Inc. United States of America.

Brealey, Richard A; Myres, Stewart C; and Allen Franklin. 2011. Principles of Corporate Finance: Tenth Edition. The McGraw-Hill Companies, Inc. United States of America.

Creswell, John W. 2009. Research Design: Qualitative, Quantitative, and Mixed Methods Approaches. Third Edition. SAGE publication Inc. USA

Dwight C. Anderson. 1987. Study guide and workbook to accompany. Foundation of financial leverage. United States of America

Ehrhardt, Michael C; Brigham, Eugene. 2011. Financial Management: Theory and Practice. Thirteenth Edition. Nelson Education, Ltd. Canada

Fabozzi, Frank J; Peterson, Pamela P. 2003.

Financial Management and Analysis: Second edition. John Wiley \& Sons, Inc. New Jersey

Ghozali, Imam. 2011. Aplikasi Analisis Multivariate dengan Program IBM SPSS 19. Semarang: Badan Penerbit Universitas Diponegoro
Ghozali, Imam. 2012. Aplikasi Analisis Multivariate dengan Program IBM SPSS 20. Semarang: Badan Penerbit Universitas Diponegoro

Gibson, Charles H. 2009. Financial Reporting \& Analysis. Eleven Edition. Nelson Education, Ltd. USA

Hampton, John J. 2009. Fundamentals of Enterprise Risk Management: How Top Companies Assess Risk, Manage Exposure, and Seize opportunity. Amacom. USA

Horcher, Karen A. 2005. Essentials of financial risk management. John wiley \& Sons, Inc. Hoboken, New Jersey

Husnan, Suad. 1990. Manajemen Keuangan.

Teori dan Penerapan. Edisi 1. Yogyakarta: BPFE

Keown, Arthur L, et al. 2002. Financial Management: Principles and Applications: Ninth Edition. Prentice Hall. New Jersey.

Megginson, William L; Smart, Scott B; Gitman, Lawrence J. 2007. Corporate Finance: Second Edition. Education. USA Thomson Higher

Riley, Michael, et al. 2000. Researching and Writing Dissertations in Business and Management. Thomson Learning. USA

Ross, Stephen A; Westerfield, Randolph W; and Jaffe Jeffrey. 2008. Corporate Finance: Eighth Edition. The McGraw-Hill Companies, Inc. United States of America

Ross, Stephen A; Westerfield, Randolph W; and Jordan, Bradford D. 2010. 
Fundamentals of Corporate Finance: Alternate Edition. The McGraw-Hill Companies, Inc. United States of America

Sarwono, Jonathan. 2012. Path Analysis.

Jakarta: PT Elex Media

Komputindo

Siegel, Sidney. $\quad 1987 . \quad$ Statistik Nonparametik: Untuk Ilmu-Ilmu Sosial. Jakarta: PT Gramedia

Vanderstoep, Scott W; Johnston, Deirdre D.

2009. Research Methods for Everyday Life: Blending Qualitative and Quantitative Approaches. JosseyBass. San Francisco

Water, Donald. 1993. Quantitative Methods for Business. Addison-Wesley. USA

Azhar, M. 2012. Analis: Hati-hati Beli Saham Kelompok Bakrie. Accessed on January 9, 2013. http://www.tempo.co/read/news/

2012/09/05/ 088427707/ AnalisHati-Hati-Beli-Saham-

$\underline{\text { Kelompok-Bakrie }}$

Journal

Akhtar, Shehla; et al. 2012. "Relationship between Financial Leverage and Financial Performance: Evidence from Fuel \& Energy Sector of Pakistan": European Journal of Business and Management www.iiste.org ISSN 2222-1905 (Paper) ISSN 2222-2839 (Online) Vol 4, No.11.

Alaghi, Kheder. 2011. "Financial Leverage and Systematic Risk", African Journal of Business Management Vol. 5(15).

Akinlo, O and Asaolu, T. 2012. "Profitability and Leverage:
Evidence from Nigerian Firms": Global Journal of Business Research, vol.6, No. 1.

Bhatti, Afkar Majeed; et al. 2010. "Effect of Leverage on Risk and Stock Returns: Evidence from Pakistani Companies": International Research Journal of Finance and Economics Issue 58.

Cheng, M and Tzeng, Z. 2009. The Effect of Leverage on Firm Value and How the Firm Financial Quality Influence on This Effect. Institute of Business Administration, National Chung Cheng University, Taiwan.

Gahlon, James $\mathrm{M}$ and Gentry, James A.

1982. "On The Relationship Between Systematic Risk and the Degrees of Operating and Financial Leverage", Journal of Financial Management (pre-

1986); Summer 1982; 11, 2.

Gill, Amarjit and Mathur, Neil. 2011. "Factors that Influence Financial Leverage of Canadian Firms": Journal of Applied Finance \& Banking, vol.1, no.2, 2011, 19-37.

Ojo, Akinmulegun Sunday. 2012. "The Effect of Financial Leverage on Corporate Performance of Some Selected Companies in Nigeria": Canadian Social Science Vol. 8, No. 1, 2012, pp. 85-91.

Pachori , Sachchidanand and Totala , Navindra K. 2012. "Influence of Financial Leverage on Shareholders Return and Market Capitalization: A Study of Automotive Cluster Companies of Pithampur, (M.P.), India": 2nd International Conference on Humanities, Geography and 
Economics

(ICHGE'2012)

Singapore April 28-29.

Saini, Rajni, 2012. "Impact Of Financial Leverage On Shareholders Return and Market Capitalization: Empirical Evidence Of Telecommunication Sector Companies, India", International Journal of Research in IT, Management and Engineering Volume2, Issue12.

Yoon, E and Jang, S .2005. "The Effect of

Financial Leverage on

Profitability and Risk of Restaurant

Firms," Journal of Hospitality

Financial

Management: Vol. 13: Iss. 1, Article 24.

Zhao, B and Wijewardana, W.P. 2012. "Financial Leverage, Firm Growth and Financial Strength: Evidence in Sri Lanka": Journal of Asia Pacific Business Innovation \& Technology Management 002 (2012) 013-

022 . 